\title{
FIRST RECORD OF AN AMNIOTIC EGG FROM THE ROMUALDO FORMATION (LOWER CRETACEOUS, ARARIPE BASIN, BRAZIL)
}

\author{
DAYANNE ABREU (D) \\ Departamento de Geologia, Programa de Pós-Graduação em Geologia, Universidade Federal \\ do Ceará, Campus do Pici. Av. Mister Hull, s/n, Pici, 60455-760, Fortaleza, Ceará, Brazil. \\ dayanneabreusousa@hotmail.com
}

\section{MARIA SOMÁLIA SALES VIANA (D)}

Laboratório de Paleontologia, Curso de Ciências Biológicas, Universidade Estadual Vale do Acaraú, Campus Betânia. Av. da Universidade, 850, Jerônimo de Medeiros Prado, 62010-295, Sobral, Ceará, Brazil. somalia_viana@hotmail.com

\section{PAULO VICTOR DE OLIVEIRA (D)}

Laboratório de Paleontologia de Picos, Curso de Ciências Biológicas, Universidade Federal do Piauí, Campus Senador Helvídio Nunes de Barros. Rua Cícero Duarte, 905, Bairro do Junco, 64607-670, Picos, Piauí, Brazil. victoroliveira@ufpi.edu.br

\section{GUSTAVO FERNANDES VIANA (10}

Departamento de Reprodução Animal e Radiologia Veterinária, Universidade Estadual Paulista Júlio de Mesquita Filho, Campus Botucatu. Rua Prof. Doutor Walter Maurício Correa, s/n, Campus de Botucatu, 18618-681, Botucatu, São Paulo, Brazil. medvetgust@hotmail.com

DIVA MARIA BORGES-NOJOSA

Departamento de Biologia, Núcleo Regional de Ofiologia, Universidade Federal do Ceará, Campus do Pici. Av. Mister Hull, s/n, Pici, 60455-760, Fortaleza, Ceará, Brazil. dmbnojosa@gmail.com

\begin{abstract}
Fossil amniotic eggs have great informative potential, especially regarding reproductive and evolutionary aspects of vertebrates. However, there are only few intact specimens or with fossilized embryos within, and the rare reported cases are mostly related to dinosaurs. In Brazil, the records of these ichnofossils are practically restricted to the Bauru Basin. This research aims to describe the first amniotic egg found in carbonate concretions in the Romualdo Formation, adding information to the study of these fossils and to the paleontological context of the basin. The specimen was collected at the Sítio Pé da Serra do Félix, in the Municipality of Simões, Piauí State, Brazil. The methodology employed was based on Scanning Electron Microscopy, Energy Dispersive Spectroscopy and Optical Microscopy techniques, as well as computed tomography analyses. The morphological and microstructural characteristics of the shell suggests the identification of the fossil as a crocodylomorph egg. This specimen differs from other fossil eggs assigned to the aforementioned group by its small size and considerably thick shell. The tomographic sections revealed possible basic structures of an embryo inside the egg, suggesting that this is the first fossilized egg with a crocodylomorph embryonic trace found in the world.
\end{abstract}

Keywords: ichnofossil, amniotic egg, embryo, Crocodylomorpha, Aptian, Romualdo Formation. 
RESUMO - Ovos amnióticos fósseis possuem um grande potencial informativo, especialmente em relação aos aspectos reprodutivos e evolutivos dos vertebrados. Contudo, existem poucos exemplares intactos ou dotados de vestígios embrionários em seu interior e os raros casos registrados são em sua maioria relacionados a dinossauros. No Brasil, os registros desses icnofósseis estão praticamente restritos a Bacia Bauru. O presente trabalho objetiva descrever a primeira ocorrência de um ovo amniótico encontrado em concreções carbonáticas da Formação Romualdo, acrescentando informações ao estudo desses fósseis e ao contexto paleontológico da bacia. O espécime foi coletado no Sítio Pé da Serra do Félix, no Município de Simões, Piauí, Brasil. A metodologia empregada baseou-se nas técnicas de Microscopia Eletrônica de Varredura, Espectroscopia por Energia Dispersiva e Microscopia Óptica, bem como análises de tomografia computadorizada. As características morfológicas e microestruturais da casca sugerem que o fóssil se trata de um ovo de crocodilomorfa. O espécime analisado difere de outros ovos fósseis atribuídos ao referido grupo taxonômico pelo tamanho reduzido e casca consideravelmente espessa. As seções tomográficas revelaram possíveis estruturas básicas de um embrião no interior do material, sugerindo que se trata do primeiro ovo fossilizado de crocodilomorfa com restos embrionários do mundo.

Palavras-chave: icnofóssil, ovo amniótico, embrião, Crocodylomorpha, Aptiano, Formação Romualdo.

\section{INTRODUCTION}

The formation of an ichnofossil involves three main factors: the producer, the preserved behavior pattern, and the substrate and sediment types that allowed its preservation. The relevance of the study of an ichnofossil is the aid in paleoenvironmental and paleoecological interpretations of organic activities in a given geological time, as well as highlighting the behavior of different organisms and the sedimentation conditions in the past (Souto, 2017). As such, fossilized amniotic eggs are very important as they contribute to elucidate the reproductive and evolutionary aspects of vertebrates, especially if they harbor embryos. However, these fossils are very rare due to their fragility, and most of the record is of dinosaurs, with reports of nests, complete or fragmented eggs, and also the occurrence of embryonic integument (Mikhailov, 1997; Chiappe et al., 1998; Chiappe et al., 2001; Grellet-Tinner et al., 2004, 2012; Srivastava et al., 2015).

In Brazil, fragmented eggshells and complete eggs of dinosaurs, crocodylomorphs, chelonians and birds documented from Cretaceous rocks occur mainly in the southeast region, in the sediments of the Upper Cretaceous Bauru Basin (Marsola, 2013; Marsola et al., 2014a,b; MagalhãesRibeiro, 2017). In the northeast, there are only occurrences of putative eggshells of uncertain taxonomic affinities from the Aliança Formation (Upper Jurassic, Jatobá Basin) in the Pernambuco State (Silva et al., 2012), of eggshells ascribed to dinosaurs from the Itapecuru Formation (Lower Cretaceous, Parnaíba Basin) in the Maranhão State (Vicalvi et al., 1993), and of a complete crocolylomorph egg from the Crato Formation (Lower Cretaceous, Araripe Basin) in the Ceará State (Magalhães-Ribeiro et al., 2011).

The Crato and Romualdo formations, lithostratigraphic units that compose the structural framework of the Araripe Basin, are two of the most important paleontological sites in Brazil (Viana \& Neumann, 2002). However, despite the diverse paleobiota already documented for the Romualdo Formation, especially of vertebrates (Maisey, 1991), there was still no record of amniotic eggs for this deposit. Thus, this paper aims to analyze the first record of a fossil egg, possibly from Crocodylomorpha, collected in the sedimentary layers of the Romualdo Formation.

\section{GEOLOGICAL SETTING}

Located in north-eastern Brazil, the Araripe Basin originated from processes associated with the rifting of the supercontinent Gondwana, which led to the opening of the South Atlantic Ocean, consequently forming the South American and African continents (Matos, 1992; Assine, 2007). Between the lithostratigraphic units that constitute this basin, the Santana Group is the most important from a paleontological point of view as it has two Lagerstätte deposits: the Crato and Romualdo formations (Kellner, 2002; Viana \& Neumann, 2002; Carvalho \& Santos, 2005).

The Romualdo Formation, composed by basal sandstones overlapped by greenish marls and fossil-rich calcareous concretions, marks an important marine ingression in the northeast of Brazil during the late Aptian (Custódio et al., 2017; Teixeira et al., 2017). Its fossiliferous association includes plants, invertebrates, and mainly vertebrates, with a predominance of the Osteichthyes and Pterosauria groups, but including Testudines, Crocodylomorpha and Dinosauria as well (Santos \& Valença, 1968; Kellner, 1987; Maisey, 1991; Viana \& Cavalcanti, 1991; Martill, 1993; Kellner, 1998, 2002; Kellner \& Tomida, 2000; Oliveira \& Kellner, 2007; Oliveira \& Romano, 2007; Lima et al., 2012; Polck et al., 2015; Custódio et al., 2017). From a mass mortality event (Martill, 1988; Maisey, 1991; Viana \& Sial, 1999), the eodiagenesis of concretions allowed the extraordinary preservation of these fossils, including fragile materials (Kellner, 2002).

The studied material was collected on the western border of the Araripe Basin, in the state of Piauí, in the upper part of the Romualdo Formation. This stratigraphical level is recognized in many localities in the Araripe Basin and is marked by the occurrence of coquinas, indicating the top of the Aptian in the proximal marine environment (Viana \& Long, 1997; Assine et al., 2014; Custódio et al., 2017). The stratigraphic section of the local outcrop shows a sequence of layers, approximately six meters thick of the total exhibition, consisting of greenish to brownish shales, with concretions and presenting lenses (upper meter), both carbonated, placed discordantly on the crystalline basement. At the site, several concretions containing coprolites and fish remains were also collected. In addition, the upper levels presented bioturbations and other fossils that are still being studied by algal and marine 
invertebrate specialists. The fossil here studied was collected $2.6 \mathrm{~m}$ from the top of the Romualdo Formation (Figure 1).

\section{MATERIAL AND METHODS}

The studied material consists of one isolated egg preserved in a calcareous concretion. The specimen was collected in 2015 at the locality Sítio Pé da Serra do Félix (7³5’33.0’'S/ 4044'36.1'W, datum SIRGAS 2000), in the Municipality of Simões, southeast of the Piauí State. The project authorization number is COPAL/ANM 000.822/2015. The fossil material is deposited in the fossil collection of the Museu Dom José (MDJ), located in the Municipality of Sobral, in the State of Ceará, with the designations of MDJ Ic-069a and MDJ Ic069b (Figure 2), corresponding to the part and counterpart of the same concretion.
The fossil egg was enveloped by a calcareous concretion. For this reason, only small fragments were removed from its shell and subjected to the Scanning Electron Microscopy (SEM), Dispersive Energy Spectroscopy (EDS) and Optical Microscopy (OM) techniques, for visualization and analysis of morphostructural characteristics, thus maintaining the integrity of the specimen.

Three fragments, in different histological sections (external, internal, and radial surface), were observed using SEM InspectS50-FEI and with EDS at the Analytical Center of the Universidade Federal do Ceará (UFC). Only one slide with the shell in a radial section was prepared in the Laboratório de Laminação (LAMIN). Afterwards, the slide was analyzed using high resolution petrographic microscopy (Nikon $3 \mathrm{Di}, 100 \mathrm{x}$ visual acuity) with a connected camera in the Laboratório de Microscopia Eletrônica (LME). Both laboratories belong to the UFC Geology Department.
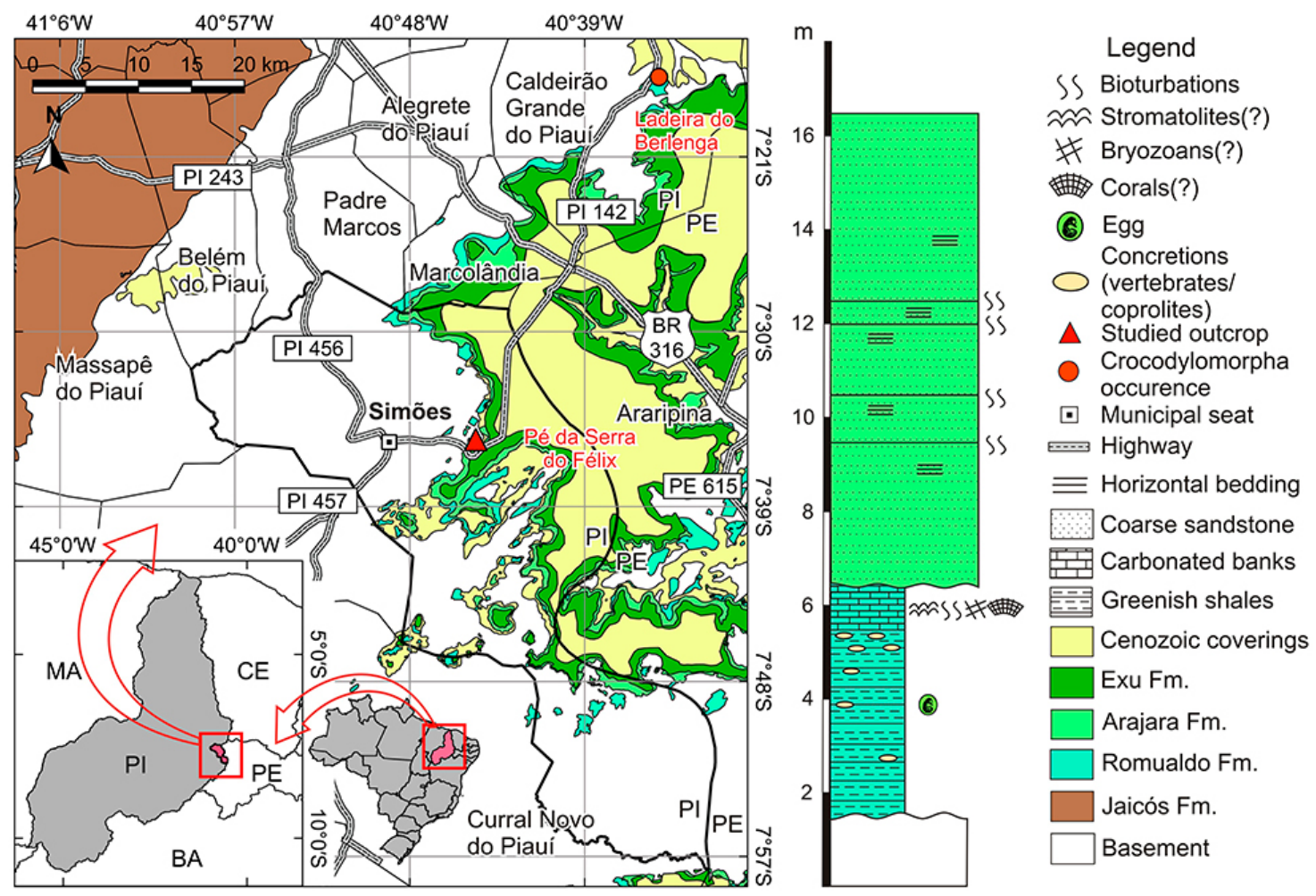

Figure 1. Location of the studied area and a local stratigraphic section with the egg occurrence horizon. Araripe Basin limits based on data provided by the Brazilian Geological Survey (CPRM Companhia de Pesquisa de Recursos Minerais: geosgb.cprm.gov.br). Processed with the QGIS software by J.V.P. Moreira in 2018.
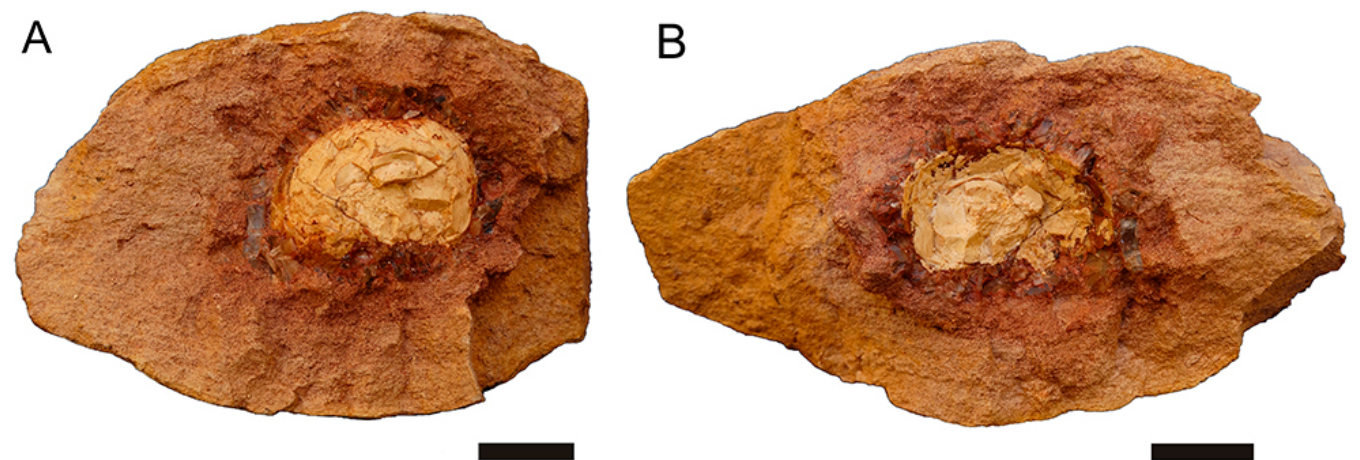

Figure 2. Fossil egg described in this study. A, MDJ Ic-069a; B, MDJ Ic-069b. Scale bars $=20 \mathrm{~mm}$. 
In addition, the specimen underwent a computed tomography in a private human radiological clinic. The use of this technique allows inferences about the interior morphology of the egg (Magalhães-Ribeiro, 2007). The examination was performed on a four-channel CT (Toshiba, model Alexion, Tokyo, Japan). The parameters used in this examination were: $120 \mathrm{kV}$ and $200 \mathrm{~mA}, 2 \mathrm{~mm}$ cross sections, and bone and soft tissues filters, whose images were reconstructed in dorsal and sagittal plane. In order to increase the contrast differentiation of the images obtained by tomography, these were stored as Digital Imaging and Communications in Medicine (DICOM) format and then transferred to the computer program of a 1.5 Tesla magnetic resonance imaging device (MRI-Siemens, Magneto Essenza, Berlin, Germany). Thus, the images were analyzed in different filters provided by the program with the objective of choosing the filter that best characterized the internal structures of the fossilized egg. Taken from a specific program for the analysis of radiological examinations (ClearCanvas Workstation version 2.0 SP1; Toronto, Canada), the images processed by the aforementioned magnetic resonance computer program were evaluated in transverse, dorsal and sagittal planes, in addition to variations of brightness, contrasts and densities based on the Hounsfield Unit.

For a better identification of the entire tomographic anatomy of the specimen, a tomographic examination was also performed on an egg of the extant species Caiman latirostris (CHUFC C048, registered in the UFC Herpetology Collection), which was in its final stage of embryonic development. These images were evaluated in a soft tissue filter in sagittal plane. The analyses were approved by the Ethic Committee on Animal Use of the Universidade Federal do Ceará (CEUA-UFC), CEUA protocol number 9806051018. After the computed tomography scan, the egg was dissected and the embryo (C. latirostris) was removed from the egg. The sagittal section was performed on the midline, corresponding to the tomographic image of the fossil specimen.

\section{RESULTS AND DISCUSSION}

\section{Description and morphological comparison}

MDJ Ic-069 presents a slightly elliptical shape, measuring $26.02 \mathrm{~mm}$ and $18.15 \mathrm{~mm}$ in its major and minor axes, respectively. The dimensions of MDJ Ic-069 are small compared to other crocodylomorph eggs from the Brazilian Cretaceous, such as a specimen from the Crato Formation (Magalhães-Ribeiro et al., 2011), or those described by Oliveira et al. (2011) and Marsola et al. (2016) from the Adamantina Formation, in the Bauru Basin. On the other hand, its size resembles eggs from the Araçatuba Formation in the Bauru Basin ascribed to Mariliasuchus amarali (MagalhãesRibeiro et al., 2006), as well as from eggs reported by Novas et al. (2009) from the Bolivian Cretaceous (Table 1).

The eggshell thickness is about $0.45 \mathrm{~mm}$, which is quite significant when compared to the egg of the Crato Formation (Magalhães-Ribeiro et al., 2011). It is more similar to the shell thickness in eggs of the living species Paleosuchus
Table 1. Comparative dimensions and shell thickness of some crocodylomorph eggs.

\begin{tabular}{ccc}
\hline Lithostratigraphic units & $\begin{array}{c}\text { Egg dimension (major } \\
\text { axis X minor, in mm) }\end{array}$ & $\begin{array}{c}\text { Shell thickness } \\
(\mathrm{mm})\end{array}$ \\
\hline Crato Formation (Brazil) & $43 \times 29$ & 0.1 \\
$\begin{array}{c}\text { Adamantina Formation } \\
\text { (Brazil) }\end{array}$ & $72.6 \times 42$ & $0.13-0.15$ \\
$\begin{array}{c}\text { Araçatuba Formation } \\
\text { (Brazil) }\end{array}$ & $35 \times 46$ & $0.15-0.25$ \\
$\begin{array}{c}\text { Lameta Formation (India) } \\
\text { Cajones Formation } \\
\text { (Bolivia) }\end{array}$ & $30 \times 50$ & $0.24-0.36$ \\
$\begin{array}{c}\text { Romualdo Formation } \\
\text { (Brazil) }\end{array}$ & $30 \times 16$ & $0.43-0.47$ \\
\hline
\end{tabular}

palpebrosus, whose average thickness is $0.41 \mathrm{~mm}$ (Marzola et al., 2015) and the specimens described by Srivastava et al. (2015) for the Indian Cretaceous, which have average thickness between $0.43-0.47 \mathrm{~mm}$. However, a shell fracture was observed through the tomography, in the left lower portion of the egg. Thus, due to this fracture and the potential loss of fluid from within the egg, it is difficult to ascertain whether the dimensions of the specimen have changed or not. In addition, this fracture may have caused changes in eggshell thickness.

The spectroscopic analysis in the eggshell basic units revealed the presence of calcium carbonate $\left(\mathrm{CaCO}_{3}\right)$, which is the predominant matter of the mineralized eggshell (Kohring, $1995)$ and, in some points, of calcium phosphate $\left(\mathrm{Ca}_{3}\left(\mathrm{PO}_{4}\right)_{2}\right)$, as well as the presence of Barium (Ba) and Sulphur (S) (Figure 3). The latter two elements may be related to decomposition processes in the marine environment (Dehairs et al., 2000; Reitz et al., 2004).

The eggshell outer surface is smooth, presenting low undulations, with pore openings randomly distributed. Such structures may be interconnected, forming larger openings, similar to the material described by Moreno-Azanza et al. (2015) (Figures 4A-B). These pore openings were also observed on the inner surface, although it is not possible to measure the quantitative data of these structures due to the restricted analyzed material (only one sample), as previously mentioned. In the radial section of the shell, the basic units individually exhibit the typical crocodylomorph pattern, consisting of polycrystalline units of calcite in the form of compact wedges, with small interstices in its bulbous base (Figures 4C-D) (e.g. Mikhailov, 1997; Oliveira et al., 2011; Marsola, 2013; Moreno-Azanza et al., 2015; Russo et al., 2017). Since the crystals are not visualized through the entire radial section, a certain limitation was verified when observing these structures. In addition, the calcite layers or tabular microcrystallisations that have developed along the basic units are poorly highlighted. The configuration of the basic unit of the shell is much more evident using optical microscopy, which reaffirms the aforementioned descriptions (Figures 4E-F). However, with only one single sample to analyze, it was impossible to determine more details. The tabular 


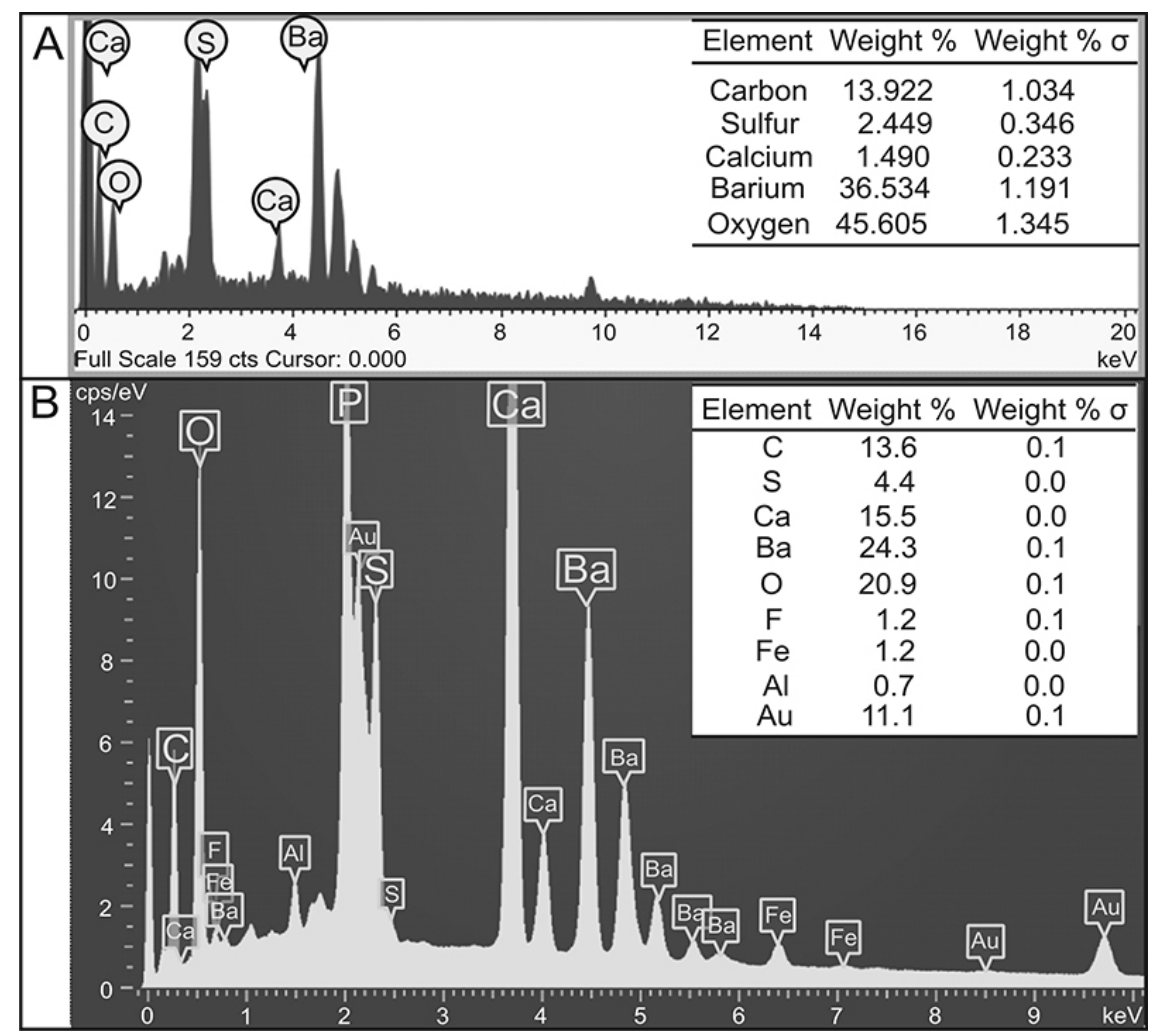

Figure 3. Spectrum of the elements identified in the eggshell. A, calcium carbonate; $\mathbf{B}$, calcium phosphate.

microcrystallization is present in the crocodile eggshell units (Erben, 1970; Ferguson, 1982; Mikhailov, 1997) and is used as a diagnostic feature for the identification of crocodylomorph fossil eggs.

It is worth noting that the analysis of microstructural characters related to the crystalline structure of the egg shell, composed of the basic units of the shell and the pore system, is essential to associate the fossil egg to the producing animal group, since each amniote vertebrate taxon exhibits a characteristic pattern of this structure (Magalhães-Ribeiro, 2017). Thus, it is possible to make taxonomic assignments of these ichnofossils based on the microstructure of the eggshell (Mikhailov et al., 1996; Magalhães-Ribeiro, 2007). In the fossilized or recent eggs of crocodylomorph, the characteristics observed in the shell microstructure are consistently different from those of other amniotes, thus allowing a conclusive taxonomic attribution (Russo et al., 2017).

In the case of MDJ Ic-069, the limitation of samples analyzed in both SEM and optical microscopy hindered a more accurate diagnosis. Thus, the studied specimen is tentatively associated with crocodylomorph, based mainly on the configuration of the basic shell units, in addition to the other morphological characteristics presented.

\section{Tomographic data}

In the tomographic images of MDJ Ic-069, an embryolike internal structure could be detected. The study of these findings is usually based on the observation of anatomical patterns in living taxa of the same group, which aim to explain and correlate the existent structures in the fossil specimen and the degree or type of its development (Azevedo et al., 2000; Andrade, 2005; Balanoff et al., 2008). Thus, the tomographic image of both the fossilized specimen and the egg of the extant species, as well as the anatomical section of the respective embryo (Caiman latirostris), were anatomically correlated. This comparison allowed us to suggest an embryo-shaped image in the sagittal plane, as well as specific structures such as: eggshell, brain cavity, vertebral column and abdominal region (Figure 5).

The densities of the main regions present in the fossilized egg were quantified according to the Hounsfield Unit (Cogbill $\&$ Ziegelbein). This allows for the indication of more specific regions of the supposed embryo, according to density proportions corresponding to embryonic structures such as: skull, vertebrae and abdominal region. However, other regions of the fossilized embryo body and some anatomical details could not be identified due to the quality of the tomographic images, the initial state of ossification, or the small size or wear of anatomical structures (Schweitzer et al., 2002; Balanoff et al., 2008).

In the case of MDJ Ic-069, the taphonomic processes probably caused a change in the conservational state of the egg. Together with the substitution and mineralization of the soft tissues, this may have contributed to the lack of definition and to the increase of density of the caudal portion of the embryo, as well as to the loss of anatomical details such as the temporal cavities identified in crocodylians. Thus, it was not possible to specify the tomographic anatomy and to correlate it with the macroscopic anatomy of the crocodylomorph species of the Romualdo Formation - Araripesuchus gomesii 


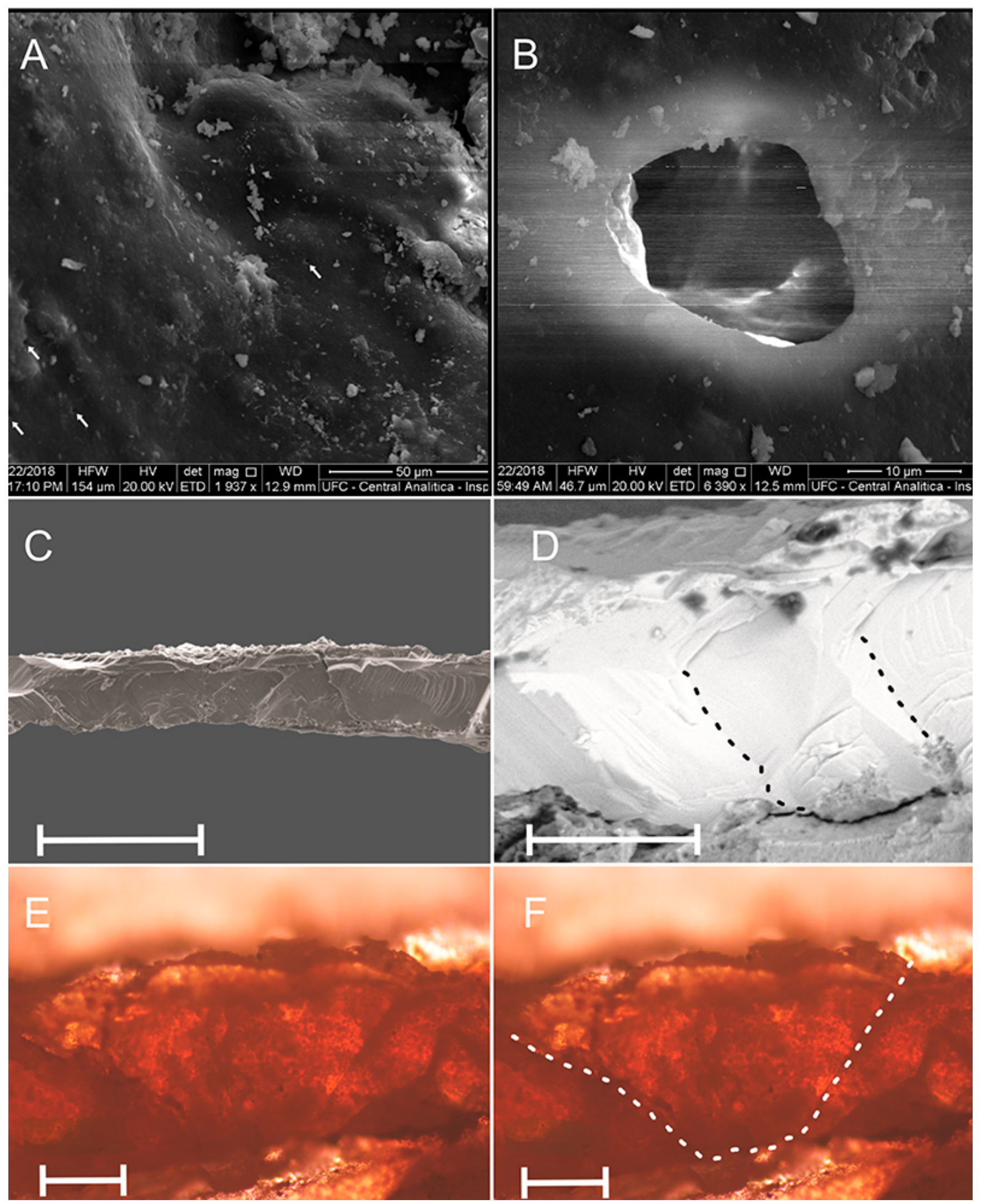

Figure 4. Microscopy analysis in MDJ Ic-069. Scanning Electron Microscope. A, outer surface of the shell exhibiting undulations, with pore openings randomly distributed (arrows); B, openings caused by interconnected pores; $\mathbf{C}-\mathbf{D}$, radial section of the shell; the lines indicate the boundaries between each unit of the shell. Optical microscope; $\mathbf{E}-\mathbf{F}$, configuration of the basic shell unit and its outline. Scale bars: C, E-F $=200 \mu \mathrm{m} ; \mathrm{D}=50 \mu \mathrm{m}$. 

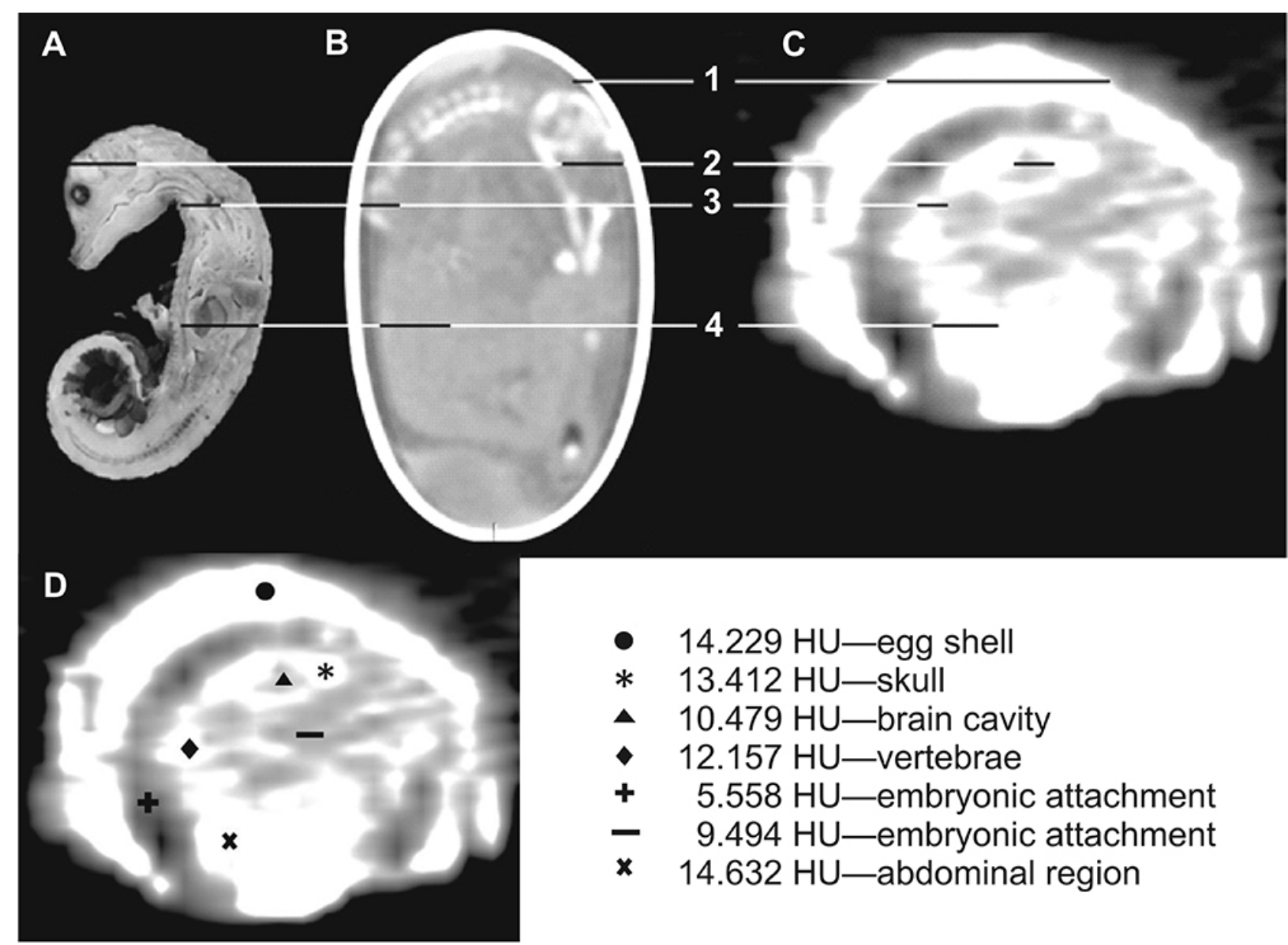

Figure 5. Correlation of the main anatomic characteristics of a present crocodylian embryo (Caiman latirostris) and MDJ Ic-069. A, sagittal section of $C$. latirostris; $\mathbf{B}$, tomographic image of $C$. latirostris still inside the egg; $\mathbf{C}$, tomographic fossil image (1, eggshell; 2, skull; 3, vertebral column; 4, abdominal region); D, approximate values of the densities in Hounsfield Unit (HU) and suggestions of the involved structures of the specimen.

or Itasuchus camposi (Price, 1959; Kellner, 1987; Riff et al., 2012).

Even though it is not possible to identify the new discovery taxonomically, it is worth noting the presence of Araripesuchus gomesii in the same strata, in a locality about $38.5 \mathrm{~km}$ away from where the egg was found (Figure 1). Although suggestive, it is premature to assign this species as a possible producer due to the absence of osseous elements in association with the fossil egg, as established by the taxonomic confidence levels proposed by Grellet-Tinner (2005).

\section{CONCLUSION}

The analysis of the morphostructural characteristics observed in the shell of MDJ Ic-069 allowed us to present the first possible record of crocodylomorph egg from the Romualdo Formation in the Araripe Basin. This specimen differs from other fossil eggs attributed to the Crocodylomorpha by its small size and the considerably thick shell. Possible basic anatomical structures of a body embryo were recognized. Thus, MDJ Ic-069 could be the first fossil egg in the world with embryonic remains attributed to crocodylomorphs.

\section{ACKNOWLEDGMENTS}

The authors thank the Universidade Estadual Vale do Acaraú (Sobral, Brazil) and the Universidade Federal do Piauí (Picos, Brazil) for the partnership that led to the collection of the studied specimen, and also for the infrastructure available; to M.J. Gomes de Sousa (UFC, Fortaleza, Brazil), F.D. Sales (UFC, Fortaleza, Brazil), J.V.P. Moreira (Universidade Federal do Rio de Janeiro, Rio de Janeiro, Brazil), A.H. Fernandes Júnior for fieldwork assistance, and to F.P. Félix, who kindly allowed the access to his property, where the study area is located; to the board of the MDJ for the space provided for the development of the research; to the Analytical Centre, LAMIN and LME for the analyses performed on the material; to the Criatório Mister Cayman (Maceió, Brazil) for the donated oological material; to the radiologic technologist Á. Fontes (Clínica Boghos Boyadjian, Fortaleza, Brazil), for his observations and help in the treatment of tomographic images; to the Pathovet Veterinary Laboratory (Fortaleza, Brazil) for the assistance and for providing the appropriate equipment required for the anatomical cutting of the egg belonging to Caiman latirostris; to the Coordenação de Aperfeiçoamento de Pessoal de Nível Superior (CAPES)-Finance Code 001, for the scholarship awarded to D. Abreu; and to the Conselho 
Nacional de Desenvolvimento Científico e Tecnológico (CNPq) for a research fellowship (Process number PQ 311961/2016-9) awarded to D.M. Borges-Nojosa. The authors also thank two anonymous referees for their valuable draft contributions.

\section{REFERENCES}

Andrade, M.B. 2005. Revisões sistemática e taxonômica dos Notosuchia (Metasuchia, Crocodylomorpha). Programa de Pós-Graduação em Geologia Regional, Universidade Estadual Paulista, Dissertação de Mestrado, 239 p.

Assine, M. 2007. Bacia do Araripe. Boletim de Geociências da Petrobrás, 15:371-389.

Assine, M.; Perinotto, J.A.J.; Andriolli, M.C.; Neumann, V.H.; Mescolotti, P.C. \& Varejão, F. G. 2014. Sequências deposicionais do Andar Alagoas da Bacia do Araripe, Nordeste do Brasil. Boletim de Geociências da Petrobras, 22:3-28.

Azevedo, S.A.; Gallo, V. \& Ferigolo, J. 2000. A possible chelonian egg from the Brazilian late cretaceous. Anais da Academia Brasileira de Ciências, 72:187-193. doi:10.1590/S000137652000000200007

Balanoff, A.M.; Norell, M.A.; Grellet-Tinner, G. \& Lewin, M.R. 2008. Digital preparation of a probable neoceratopsi an preserved within an egg, with comments on microstructural anatomy of ornithischian eggshells. Naturwissenschaften, 95:493-500. doi:10.1007/s00114-008-0347-2

Carvalho, M.S.S. \& Santos, M.E.C.M. 2005. Histórico das pesquisas paleontológicas na Bacia do Araripe, Nordeste do Brasil. Anuário do Instituto de Geociências, 28:15-34.

Chiappe, L.M.; Coria, R.A.; Dingus, L.; Jackson, F.; Chinsamy, A. \& Fox, M. 1998. Sauropod dinosaur embryos from the Late Cretaceous of Patagonia. Nature, 396:258-261. doi: $10.1038 / 24370$

Chiappe, L.M.; Salgado, L. \& Coria, R.A. 2001. Embryonic skulls of titanosaur sauropod dinosaurs. Science, 293:2444-2446. doi:10.1126/science.1063723

Cogbill, T.H. \& Ziegelbein, K.J. 2011. Computed tomography, magnetic resonance, and ultrasound imaging: basic principles, glossary of terms, and patient safety. Surgical Clinics of North America, 91:1-14. doi:10.1016/j.suc.2010.10.006

Custódio, M.A.; Quaglio, F.; Warren, L.V.; Simões, M.G.; Fürsich, F.T.; Perinotto, J.A.J. \& Assine, M.L. 2017. The transgressiveregressive cycle of the Romualdo Formation (Araripe Basin): sedimentary archive of the Early Cretaceous marine ingression in the interior of Northeast Brazil. Sedimentary Geology, 359:1-15. doi:10.1016/j.sedgeo.2017.07.010

Dehairs, F.; Fagel, N.; Antia, A.N.; Peinert, R.; Elskens, M. \& Goeyens, L. 2000. Export production in the Bay of Biscay as estimated from barium - barite in settling material: a comparison with new production. Deep Sea Research Part I, Oceanographic Research Papers, 47:83-601. doi:10.1016/ S0967-0637(99)00072-2

Erben, H. 1970. Ultrastrukturen und Mineralisation rezenter und fossiler Eischalen bei Vogeln und Reptilien. Biomineralisation Forschungsberichte, 1:1-66.

Ferguson, M.W.J. 1982. The structure and composition of the eggshell and embryonic membranes of Alligator mississippiensis. Transactions of the Zoological Society of London, 36:99-152. doi:10.1111/j.1096-3642.1982.tb00064.x
Grellet-Tinner, G. 2005. A phylogenetic analysis of oological characters: a case study of saurischian dinosaur relationships and avian evolution. University of Southern California, Ph.D. Dissertation, $234 \mathrm{p}$.

Grellet-Tinner, G.; Chiappe, L.M. \& Coria, R. 2004. Eggs of titanosaurid sauropods from the Upper Cretaceous of Auca Mahuevo (Argentina). Canadian Journal of Earth Sciences, 41:949-960. doi:10.1139/e04-049

Grellet-Tinner, G.; Codrea, V.; Folie, A.; Higa, A. \& Smith, T. 2012. First evidence of reproductive adaptation to "Island Effect" of a dwarf Cretaceous Romanian titanosaur, with embryonic integument in ovo. PLoS ONE, 7:e32051. doi:10.1371/journal. pone.0032051

Kellner, A.W.A. 1987. Ocorrência de um novo crocodiliano no Cretáceo Inferior da Bacia do Araripe, Nordeste do Brasil. Anais da Academia Brasileira de Ciências, 59:219-232.

Kellner, A.W.A. 1998. Panorama e perspectiva do estudo de répteis fósseis no Brasil. Anais da Academia Brasileira de Ciências, 70:647-676.

Kellner, A.W.A. 2002. Membro Romualdo da Formação Santana, Chapada do Araripe, CE - um dos mais importantes depósitos fossíliferos do Cretáceo brasileiro. In: C. Schobbenhaus; D.A. Campos; E.T. Queiroz; M. Winge \& M.L.C. Berbet-Born (eds.) Sítios Geológicos e Paleontolológicos do Brasil, Departamento Nacional de Produção Mineral, p. 121-130.

Kellner, A.W.A. \& Tomida, Y. 2000. Description of a new species of Anhangueridae (Pterodactyloidea) with comments on the pterosaur fauna from the Santana Formation (Aptian-Albian), Northeastern Brazil. Tokyo, Natural Science Museum, 135 p. (Monographs 17).

Kohring, R. 1995. Reflection son the origin of the amniote egg in the light of reproductive strategies and shell structure. Historical Biology, 10:259-275. doi:10.1080/10292389509380524

Lima, F.J.; Saraiva, A.A.F. \& Sayão, J.M. 2012. Revisão da paleoflora das formações Missão Velha, Crato e Romualdo, Bacia do Araripe, Nordeste do Brasil. Estudos Geológicos, 22:99-11. doi:10.18190/1980-8208/estudosgeologicos.v22n1p99-115

Magalhães-Ribeiro, C.M. 2007. Ovos fossilizados de vertebrados. In: I.S. Carvalho \& A.C.S. Fernandes (eds.) Icnologia, SBG, p. 74-83.

Magalhães-Ribeiro, C.M. 2017. Ovos fósseis. In: P.R.F. Souto (org.) Icnologia de Paleovertebrados, Letra Capital, p. 33-56.

Magalhães-Ribeiro, C.M.; Carvalho, I.S.; Freitas, I.F. \& Andrade, J.A.F.G. 2011. Um ovo de Crocodiliforme do Cretáceo inferior da Bacia do Araripe. In: I.S. Carvalho; N.K. Srivastava; O. Strohschoen Jr. \& C.C. Lana (eds.) Paleontologia: cenários de vida, Interciência, p. 663-668.

Magalhães-Ribeiro, C.M.; Carvalho, I.S. \& Nava, W.R. 2006. Ovos de crocodilomorfos da Formação Araçatuba (Bacia Bauru, Cretáceo Superior), Brasil. In: V. Gallo; M.P. Brito; H.M.A. Silva $\&$ F.J. Figueiredo (eds.) Paleontologia de vertebrados, grandes temas e contribuições científicas, Interciência, p. 285-292.

Maisey, J.G. 1991. Santana fossils: an illustrated atlas. Neptune City, Tropical Fish Hobbyist, 459 p.

Marsola, J.C.A. 2013. Novos registros de ovos fósseis de vertebrados do Cretáceo Superior do Grupo Bauru. Universidade de São Paulo, Dissertação de Mestrado, 81 p.

Marsola, J.C.A.; Batezelli, A.; Montefeltro, F.C.; Grellet-Tinner, G. \& Langer, M.C. 2016. Palaeoenvironmental characterization of a crocodilian nesting site from the Late Cretaceous of Brazil and the evolution of crocodyliform nesting strategies. 
Palaeogeography, Palaeoclimatology, Palaeoecology, 457:221231. doi:10.1016/j.palaeo.2016.06.020

Marsola, J.C.A.; Grellet-Tinner, G.; Montefeltro, F.C. \& Langer, F.C. 2014a. The first Pan-Podocnemididae turtle egg from the Presidente Prudente Formation (Late Cretaceous, Bauru Group), Brazil. Zootaxa, 872:187-194. doi:10.11646/zootaxa.3872.2.5

Marsola, J.C.A.; Grellet-Tinner, G.; Montefeltro, F.C.; Sayão, J.M.; Hsiou, A.S. \& Langer, M.C. 2014b. The first fossil avian egg from Brazil. Alcheringa, 38:1-5. doi:10.1080/03115518.201 4.926449

Martill, D.M. 1988. Preservation of fish in the Cretaceous Santana Formation of Brazil. Palaeontology, 31:1-18.

Martill, D.M. 1993. Fossils of the Santana and Crato Formations, Brazil. London, The Palaeontological Association, 159 p. (Field Guide to Fossils 5).

Marzola, M.; Russo, J. \& Mateus, O. 2015. Identification and comparison of modern and fossil crocodilian eggs and eggshell structures. Historical Biology, 27:115-133. doi:10.1080/08912 963.2013.871009

Matos, R.M.D. 1992. The Northeastern Brazilian rift system. Tectonic, 11:766-791. doi:10.1029/91TC03092

Mikhailov, K.E. 1997. Fossil and recent eggshells in amniotic vertebrates: fine structure, comparative morphology and classification. London, The Palaeontological Association, 80 p. (Special Papers in Palaeontology 56).

Mikhailov, K.E.; Bray, E.S. \& HIRSCH, K.F. 1996. Parataxonomy of fossil egg remains (Veterovata): principles and applications. Journal of Vertebrate Paleontology, 16: 763-769. doi:10.1080 102724634.1996.10011364

Moreno-Azanza, M.; Canudo, J.I. \& Gasca, J.M. 2015. Enigmatic Early Cretaceous ootaxa from Western Europe with signals of extrinsic eggshell degradation. Cretaceous Research, 56:617627. doi:10.1016/j.cretres.2015.06.019

Novas, F.; Pais, D.F.; Pol, D.; Carvalho, A.B.; Scanfalera, A.; Mones, A. \& Riglos, M.S. 2009. Bizarre Notosuchian crocodyliform with associated eggs from the Upper Cretaceous of Bolivia. Journal of Vertebrate Paleontology, 29:1316-1320. doi:10.1671/039.029.0409

Oliveira, C.E.M.; Santucci, R.M.; Andrade, M.B.; Fulfaro, V.J.; Basílio, J.A.F. \& Benton, M.J. 2011. Crocodylomorph eggs and eggshells from the Adamantina Formation (Bauru Group), Upper Cretaceous of Brazil. Palaeontology, 54:309-321. doi:10.1111/j.1475-4983.2010.01028

Oliveira, G.R. \& Kellner, A.W.A. 2007. A new side-necked turtle (Pleurodira, Pelomedusoides) from the Santana Formation (Early Cretaceous), Araripe Basin, Northeastern Brazil. Zootaxa, 1425:53-61. doi:10.11646/zootaxa.1425.1.7

Oliveira, G.R. \& Romano, P.S.R. 2007. Histórico dos achados de tartarugas fósseis do Brasil. Arquivos do Museu Nacional, 65:113-133.

Polck, M.A.R.; Carvalho, M.S.S.; Miguel, R. \& Gallo, V. 2015. Guia de identificação de peixes fósseis das Formações Crato e Santana da Bacia do Araripe. Rio de Janeiro, Companhia de Pesquisa de Recursos Minerais, $72 \mathrm{p}$.

Price, L.I. 1959. Sobre um crocodilídeo notosúquio do Cretáceo brasileiro. Rio de Janeiro, Departamento Nacional de Produção Mineral, Divisão de Geologia e Mineralogia, 55 p. (Boletim 188).

Reitz, A.; Pfeifer, K.; De Lange, G.J. \& Klump, J. 2004. Biogenic barium and the detrital $\mathrm{Ba} / \mathrm{Al}$ ratio: a comparison of their direct and indirect determination. Marine Geology, 204:289-300. doi:10.1016/S0025-3227(04)00004-0
Riff, D.; Souza, R.G.; Cidade, G.M.; Martinelli, A.G. \& Souza-Filho, J.P. 2012. Crocodilomorfos: a maior diversidade de répteis fósseis do Brasil. Terrae Didatica, 9:12-40.

Russo, J.; Mateus, O; Marzola, M. \& Balbino, A. 2017. Two new ootaxa from the late Jurassic: the oldest record of crocodylomorph eggs, from the Lourinhã Formation, Portugal. PloS ONE, 12:e0171919. doi:10.1371/journal.pone.0171919

Santos, R.S. \& Valença, J.G. 1968. A Formação Santana e sua paleoictiofauna. Anais da Academia Brasileira de Ciências, 40:339-360.

Schweitzer, M.H.; Ackson, F.D.; Chiappe, L.M.; Schmitt, J.G.; Calvo, J.O. \& Rubilar, D.E. 2002. Late Cretaceous Avian eggs with embryos from Argentina. Journal of Vertebrate Paleontology, 22:191-195. doi:10.1671/0272-4634(2002)022 [0191:LCAEW E]2.0.CO;2

Silva, M.C.; Ribeiro-Magalhães, C.M.; Barreto, A.M.F.; Marinho, T.S. \& Carvalho, I.S. 2012. Casca de ovo do Neojurássico brasileiro: Formação Aliança, Bacia de Jatobá, PE. In: SIMPÓSIO BRASILEIRO DE PALEONTOLOGIA DE VERTEBRADOS, 8, 2012. Boletim de resumos, Pernambuco, SBP, p. 171.

Souto, P.R.F. 2017. Icnologia. In: P.R.F. Souto (org.) Icnologia de Paleovertebrados, Letra Capital, p. 17-32.

Srivastava, R.; Patnaik, R.; Shukla, U.K. \& Sahn, A. 2015. Crocodilian nest in a Late Cretaceous sauropod hatchery from the type Lameta Ghat locality, Jabalpur, India. PLoS ONE, 10:e144369. doi:10.1371/journal.pone.0144369

Teixeira, M.C.; Mendonça-Filho, J.G.; Oliveira, A.D. \& Assine, M.L. 2017. Faciologia orgânica da Formação Romualdo (Grupo Santana, Cretáceo Inferior da Bacia do Araripe): caracterização da matéria orgânica sedimentar e interpretação paleoambiental. Geologia USP Série Científica, 17:11-44. doi:10.11606/ issn.2316-9095.v17-347

Viana, M.S.S. \& Cavalcanti, V.M.M. 1991. Sobre a estratigrafia da Formação Santana, Bacia do Araripe. Revista de Geologia, 4:51-60.

Viana, M.S.S. \& Long, L.1997. Rb-Sr isotope data from fish scales of the Cretaceous Santana Formation Northeast Brazil. In: ANNUAL MEETING OF THE GEOLOGICAL SOCIETY OF AMERICA, 1997. Abstracts, Salty Lake city, GSA, p. 339.

Viana, M.S.S. \& Neumann, V.H.L. 2002. Membro Crato da Formação Santana, Chapada do Araripe, CE - Riquíssimo registro de fauna e flora do Cretáceo. In: C. Schobbenhaus; D.A. Campos; E.T. Queiroz; M. Winge \& M.L.C. Berbet-Born (eds.) Sítios Geológicos e Paleontológicos do Brasil, Departamento Nacional de Produção Mineral, p. 113-120.

Viana, M.S.S. \& Sial, A.N. 1999. Oxygen isotopic variation on phosphate of Albian fish scales as an indicator of environmental cyclicity. In: SOUTH AMERICAN SYMPOSIUM ON ISOTOPE GEOLOGY, 2, 1999. Boletín, Córdoba, SEGEMAR, p. 445-448.

Vicalvi, M.A.; Ferreira, C.S.; Carvalho, I.S. \& Anjos, S.M. 1993. Fragmentos de ovos de dinossauros da Formação Itapecuru, Maranhão: uma discussão. Anais da Academia Brasileira de Ciências, 65:218.

Received in 16 January, 2020; accepted in 19 May, 2020. 